\title{
ADOPTING A PARTICIPATORY APPROACH TO COMMUNITY FORESTS MANAGEMENT IN RURAL NIGERIA
}

\author{
AROWOLO A.O. ${ }^{1 *}$ \\ AGBONLAHOR M.U. ${ }^{1}$ \\ OKUNEYE P.A. ${ }^{2}$ \\ SOAGA J.A. ${ }^{2}$
}

\author{
${ }^{1}$ 1Department of Agricultural Economics and Farm Management \\ Federal University of Agriculture, Abeokuta \\ ${ }^{2}$ Department of Forestry \\ Federal University of Agriculture, Abeokuta
}

Received: $13 / 03 / 2014$

Accepted: $13 / 06 / 2014$

*to whom all correspondence should be addressed:

Available online: $21 / 10 / 2014$

e-mail: arowoshola@gmail.com

\section{ABSTRACT}

The study examined the willingness of rural households to pay for sustainable management of community forests in Southwest Nigeria. The value elicitation format used was the dichotomous choice contingent valuation technique. The multistage random sampling technique was used in selecting 180 rural households for the study. Data obtained were analyzed using descriptive statistics and logit regression analysis. Evidence from the logit model indicated that the mean willingness of rural households to pay for sustainable management of community forests was $\$ 389.04 /$ month. The result also shows that bid, perceived importance of forests, age, educational level of household head, total household income, perception of deforestation effect and intergenerational equity were the significant factors that influence the rural households' probability of willingness to pay for community forests management. The study recommends policy measures aimed at inclusion of rural communities in the management of community forests as the rural people are willing to pay for its management which will help ensure sustainable management of forest resources and as well improve the welfare of the rural households.

Keywords: Households, Willingness, Dichotomous, Contingent, Logit, South-western, Nigeria

\section{Introduction}

Forest resource is a key component of the natural resource base of any community, region or country; it plays a fundamental role in the socio-economic well-being of the people (Inoni, 2009). This is particularly so in Africa where most of the countries including Nigeria have large rural populations that depend on natural resource exploitation for their livelihood (Inoni, 2009). Over two-thirds of the 600 million people in Africa obtain a major proportion of their subsistence and cash income from the large and diverse set of forest products and forest-related activities (Arnold and Townson, 1998; Kaimowitz, 2003; CIFOR, 2005). Majority of the rural and urban households in developing countries depend on plant and animal products from the forests to meet part of their nutritional needs (Bryon and Arnold, 1997). Forest and forest trees are sources of variety of foods that supplement and complement what is obtained from agriculture (Inoni, 2009). Many agricultural communities suffer from seasonal food shortages, which usually occur at the time of the year when stored food supplies have dwindled and new crops harvest is just beginning. Forest foods and income are used extensively at such periods and during emergencies of floods, famines and droughts (Inoni, 2009). In addition, forests help to improve the quality of the environment and serve as source of natural habitat for biodiversity and repository of 
genetic wealth, provide means for recreation and opportunity for eco-tourism (Mathur and Sachdeva, 2003).

However, the tropical rainforest despite its uniqueness and extraordinary value, is highly destroyed and badly degraded at an unsustainable rate (Okojie, 2007). The United Nations (2002) reported that a great percentage of luxurious vegetation in Nigeria has been removed and several species have become extinct. FAO (2005) reported that Nigeria has the highest rate of deforestation in the world. It was said that between year 2000 and 2005, Nigeria had lost 55.7\% of its primary forest and rate of forest change due to deforestation increased to $3.12 \%$ per annum (FAO, 2005). Although Nigeria government established several forest reserves in order to conserve and manage forest resources, these forest reserves established have been seriously neglected and received little or no improvement in terms of investment and management (Chukwuone and Okorji, 2008). In addition, there are community forests also termed free areas which are forested areas that are not under strict management by the government. The community forest is the only forest resource that is closest to the local people and for which the people have unrestricted access to exploit. However, it is fast diminishing in content and scale. The unrestricted access (i.e. the open accessibility) and use of the resource presents a problem of over exploitation (tragedy of the commons), as each user will exploit the resource independent of others to maximise benefits. Also, the management of forests has not been participatory as the rural communities are rarely involved. There is therefore a need to involve the rural communities, especially in producing and implementing forest management plans, to ensure that the resources are sustainably managed. It is equally important to know the value the people attach to their forest resource.

To the best of our knowledge, there have been very few studies in Nigeria on Willingness to Pay (WTP) for community forests management despite the fact that a large chunk of the country forest resources lies in the free areas termed the community forests. Beak consultants, (1998) showed that free forest areas occupy $11,777,896$ ha compared to $2,740,887$ ha covered by the reserves. This study therefore aims at determining the willingness of households in forest communities in the rainforest region of Nigeria to pay for management of community forests using the dichotomous-choice contingentvaluation method (CVM) to ensure sustainability of the resource.

\section{Theoretical framework}

Environmental goods such as waterways, beaches, parks, forests or the air itself are public goods with no market for much of the value people derive from them; hence no direct way of measurement (Niewijk, 1994). In response to this problem, researchers have turned to an innovative technique called the contingent valuation method (CVM) (Tameko et al., 2011). The technique uses surveys that provide a detailed description of the resource, its current condition, a hypothetical improvement on its condition or decrease in the chances of its degradation, and a way in which the person would pay for the improvement such as increase in taxes or higher prices, monthly contribution or donation, tax reallocation and entrance fee (Tameko et al., 2011). The first practical application of the technique was in 1963 when Davis used surveys to estimate the value hunters and tourists placed on a particular wilderness area. Mitchell and Carson, (1989), defined the CVM as a method that uses hypothetical survey questions to elicit people's preferences for public goods by finding out what they are willing to pay (WTP) for specified improvements in them. Although it is used in many studies, the CVM is seen by many economists as suffering from hypothetical bias; the hypothetical situation may not reflect the choice a respondent would make in a real situation. The WTP estimates are also inflated because respondents do not face an actual budget constraint (Tameko et al., 2011). Furthermore, respondents may deliberately shape their answers to influence the study's outcome in a way that serves their personal interest known as strategic bias. Compliance bias occurs when the respondents shape their answers to please either the interviewer or the sponsors, especially when they do not have a wellconsidered view of the survey topic (Mitchell and Carson, 1989). Strategic bias is reduced if the sample has little or nothing to gain by undervaluing the good, while compliance bias will be reduced through careful development of the survey, training and supervision of fieldwork. Other forms of bias include 
starting-point bias (the starting bid may influence the respondent to understate or overstate actual WTP if a bidding process is used to determine WTP or WTA (Willingness to Accept); vehicle bias (a respondent may be willing to pay more depending on the hypothetical, such as entrance fees or taxes); information bias (the way information on the hypothetical program is presented, including its sequence, can affect respondent's WTP or WTA); and operational bias (the fact that the operating conditions in the hypothetical program may not approximate actual market conditions may bias result). However, proponents' argue that these biases through proper survey design and implementation can be reduced.

There are number of ways to obtain the respondents' willingness to pay (WTP) for the contingent valuation method, such as, bidding games, payment cards, and open ended questionnaires. However, the dichotomous choice contingent valuation method (DCCVM) also called referendum method as adopted for this study has become the method of choice in practical settings for environmental valuation since the National Oceanic and Atmospheric Agency (NOAA) "Blue Ribbon" panel report (NOAA, 1993) recommended it in preference to other methods (Okojie, 2007). According to Carson et al., (1995), the referendum format places the respondent in a familiar social context since it resembles the way that people often make actual choices regarding public programs. The referendum describes a choice mechanism that asks each respondent how they would vote if faced with a particular program and the prospect of paying for the program through some means such as higher taxes (Carson et al., 1995).

The theoretical framework for the empirical valuation of tropical forests management is based on the fundamental assumption that the neo-classical concept of economic value based on utility maximization behavior can be extended to non-market goods such as forests management (Okojie, 2007). Environmental services are public goods and individuals are not able to make the decision on how much is being consumed. The case of a policy designed to improve the supply of environmental services from the original level $q^{0}$ to $q^{1}$, keeping the individual's utility level constant, requires a change in expenditure (Johansson, 1993). Following Hanemann, (1984), assume that $v(p, q, y, s, \varepsilon)$ is the indirect utility function of the individual, $p$, represents the prices of the market goods, $q$, the non market good, $\varepsilon$ the stochastic component of preferences, $y$ the individual's income and $s$ her characteristics. Via the survey instrument, the individual is confronted with the possibility of a change from initial situation 0 to the proposed alternative 1 (that is from $q^{0}$ to $q^{1}>q^{0}$ ). In the survey, the researcher will inform the individual that this change will cost her a certain amount $A$ and she is then asked whether she would be in favor of it at that price. The individual will answer a 'yes' if only $v\left(p, q^{1}, y-A, s, \varepsilon\right) \geq v\left(p, q^{0}, y, s, \varepsilon\right)$ and 'no' otherwise. Hence,

$\operatorname{Pr}\left\{\right.$ response is ' $\left.Y e s^{\prime}\right\}=\operatorname{Pr}\left\{v\left(p, q^{1}, y-A, s, \varepsilon\right) \geq v\left(p, q^{0}, y, s, \varepsilon\right)\right\}$

By using the compensating variation measure, which is the quantity $\mathrm{C}$ that satisfies:

$v\left(p, q^{1}, y-C, s, \varepsilon\right)=v\left(p, q^{0}, y, s, \varepsilon\right)$. Thus, $C=C\left(p, q^{0}, q^{1}, y, s, \varepsilon\right)$ is her maximum WTP for the change from $q^{0}$ to $q^{1}$. It follows that she answers 'yes' if the stated price is less than this WTP, and 'no' otherwise. Hence, an equivalent condition to (1) is:

$\operatorname{Pr}\{$ response is 'Yes' $\}=\operatorname{Pr}\{C(p, q 0, q 1, y, s, \varepsilon) \geq A\}$

In other words, the respondent will say 'yes' when her maximum willingness to pay for the change from $q^{0}$ to $q^{1}$ is larger than or equal to the proposed bid A. For instance, when the respondent is asked whether she would pay A monetary units for a policy or a management plan aimed at improving the urban park fromq0 to q1, she will answer with a 'yes' if her willingness to pay is larger, or at least equal, to $A$. Besides, it is assumed that $C\left(p, q^{0}, q^{1,} y, s, \varepsilon\right)$ is a random variable, while the respondent's WTP for the change in $q$ is something that she herself knows, it is something that the researcher does not know but treats as a random variable.

Let $\mathrm{G}_{\mathrm{c}}(\bullet)$ be what the investigator assumes is the cumulative distribution function (cdf) of $C$, and $\mathrm{g}_{\mathrm{c}}(\bullet)$ the corresponding density function. Then (2) becomes: 
The form of the function Gc (A) determines the econometric model to be used. If the Gc $(A)$ follows logistic standard distribution and the model to estimate is linear, then (3) can be written as:

$\operatorname{Pr}\{$ response is 'Yes' $\}=\frac{1+\mathrm{e}^{\delta}}{1+\mathrm{e}^{\mathrm{a}+\mathrm{bA}}}$

Where the coefficients $\alpha$ and $\beta$ are estimated in the Logit model corresponding respectively to the constant term and the explanatory variables containing the proposed bid.

Following Hanemann (1989) the restricted mean WTP for forest management is given as:

(E)WTP $=\frac{1}{\left|\beta_{1}\right|} * \ln \left(1+\exp ^{\beta_{0}}\right)$

Where $\beta_{0}$ is the estimated constant and $\beta_{1}$ is the absolute value of the estimated coefficient on the bid amount.

\section{Methodology}

\subsection{Data collection and sampling technique}

The study was carried out in Ogun State, South-western Nigeria. The state was carved out of the old Western State in 1976. The estimated human population is 3.73 million, occupying a land area of approximately $16,400 \mathrm{~km}^{2}$ (NBS, 2008). The state is largely agrarian in nature with a large rural population who depend on subsistence agriculture and forest resources as major source of livelihood (Agbonlahor, 2010). The state has a total of nine (9) Forest Reserves which were inherited from the former Western State. The reserves altogether cover an area of 2,732.62sq.km, which is about $16 \%$ of the total land mass of Ogun State and spread across the three Senatorial Districts of the State (Ogun State government).

The data for the study were from primary sources. The primary data were obtained from a field survey of rural communities selected using a combination of multistage and random sampling technique. The contingent valuation survey provided the basis for the valuation of forest management benefits. There was a pre-test open-ended contingent valuation survey that helped to determine the bid amounts elicited in the actual dichotomous-choice contingent valuation method (DC-CVM). The goal was to ask how much the respondents' were willing to pay for the management of community forests in the study area. The data generated were used to develop the bid vectors $\left(b_{1} \ldots . . b_{m}\right)$. The Bergland et al., (1987), approach as used by Okojie, (2007), was used in selecting the unique bid amounts $\left(b_{1}, b_{2}, \ldots, b_{m}\right)$ to be used in eliciting willingness to pay in the DC-CVM survey. It involved the choice of unique bids based upon equal linear increments between the lower and upper bounds of the pre-test open-ended contingent survey data. This resulted in the choice of 11 unique bid amounts used in the actual dichotomous-choice contingent valuation survey. This agrees with the $10-15$ bid amounts that have always been used in such studies according to Cooper, (1993) and as used by Okojie, (2007).

Following Okojie (2007), in other to determine optimal sample allocation to the selected bids, the pretest open-ended contingent valuation survey generated bid amounts were grouped into ten with each of the chosen bid amounts in each group. The proportion of respondents with the acceptance probability (i.e. those who answered yes) to the bids elicited in each group was found of the total in all groups. These various fractions in each group of the total sample size $(N)$ in the actual DC-CVM survey gave the various optimal sample allocations to the various bids chosen. The selected bid amounts were used in the DC-CVM survey which was carried out by randomly administering the various unique bid amounts among the various households selected for the study. The administered bid amounts elicited the household's willingness to pay (yes/no) for community forests management in the study area. A 
total of 180 rural households were selected for the study. However, data from 140 households were found useful for the analysis.

\subsection{Analytical procedure}

The descriptive analytical tools consisting of frequency, mean and standard deviation were used to describe the socio-economic variables of the respondents. Logit model was used to determine the mean willingness to pay of households for community forests management and the factors influencing their willingness to pay. The households mean willingness to pay for the management of community forests was obtained by regressing the responses of the households to the willingness to pay question on the prices (bid) they were asked to pay for the improved service and analysed using the logit regression model specified by Yusuf et al., (2007) and as used by Omonona and Fajimi, (2011) below:

$Y=\frac{1}{1+\exp ^{-\left(\beta_{0}+\beta_{1} X\right)}}$

Where:

$Y=$ Response of households to the willingness to pay question which is either 1 if yes or 0 if no.

$X=$ the price ( $\#$ ) that the household was asked to pay for the improved service (bid).

The coefficient estimates obtained were then used to calculate the mean willingness to pay of the households using the formula derived by Hanemann (1989) as used by Yusuf et al., (2007), Okojie, (2007) and Omonona and Fajimi, (2011). The formula is given as:

MeanWTP $=\frac{1}{\left|\beta_{1}\right|} * \ln \left(1+\exp ^{\beta_{0}}\right)$

Where;

$\beta_{0}=$ constant

$\beta_{1}=$ absolute value of the coefficient of the bid.

Mean WTP = the mean willingness to pay of households for community forests management.

The logit model was equally used to determine the factors that influence the households' probability of acceptance of the bid offered for the management of community forests. The household's responses to the willingness to pay question were regressed on the prices they were asked to pay and on other socioeconomic characteristics and environmental attitudinal variables of the households and analysed using the logit regression model as specified by Yusuf et al., (2007) and as used by Omonona and Fajimi, (2011).

$Y=\frac{1}{1+\exp ^{-2}}$

Where;

$\mathrm{Y}$ is dependent variable (Responses of the household to willingness to pay question which is either 1 if yes or 0 if no)

$Z=\beta_{0}+\beta_{1} V_{1}+\beta_{2} V_{2}+\ldots \ldots \ldots+\beta_{13} V_{13}$

$\beta_{0}=$ constant

$\beta_{1} \ldots . \beta_{13}=$ coefficients of the explanatory variables $V_{1} \ldots \ldots . . . V_{13}$ that are hypothesized to influence WTP including the bid amount (i.e. prices offered) which are defined in Table 1 and 2 . 
Table 1. Description of Socio-economic Variables in the Logit Model

\begin{tabular}{|c|c|c|c|}
\hline Variable & Description of variable & $\begin{array}{l}\text { Hypothesized } \\
\text { relationship with } \\
\text { WTP }\end{array}$ & Source \\
\hline $\operatorname{Bid}\left(V_{1}\right)$ & $\begin{array}{l}\text { The price that the household is } \\
\text { asked to pay monthly for the } \\
\text { improved service ( }\end{array}$ & Negative & $\begin{array}{l}\text { Loomis et al., 1994; Marchand, 1998; } \\
\text { Sansa and Kaseke, 2004; Okojie, 2007; } \\
\text { Omonona and Fajimi, } 2011\end{array}$ \\
\hline Age $\left(V_{2}\right)$ & $\begin{array}{l}\text { Age of the household head } \\
\text { (Years) }\end{array}$ & Negative & $\begin{array}{l}\text { Loomis et al., 1994; Marchand, 1998; } \\
\text { Sansa and Kaseke, 2004; Yusuf et al., } \\
\text { 2007; Omonona and Fajimi, } 2011\end{array}$ \\
\hline $\begin{array}{c}\text { Gender } \\
\left(\mathrm{V}_{3}\right)\end{array}$ & $\begin{array}{l}\text { Gender of the household head ( } 1 \\
=\text { Male, } 0=\text { Female) }\end{array}$ & Positive & Okojie, 2007 \\
\hline $\begin{array}{c}\text { Marital } \\
\text { status }\left(\mathrm{V}_{4}\right)\end{array}$ & $\begin{array}{l}\text { Marital status of the household } \\
\text { head ( } 1=\text { Married, } 0=\text { Otherwise) }\end{array}$ & Positive & $\begin{array}{l}\text { Loomis et al., 1994; Marchand, 1998; } \\
\text { Sansa and Kaseke, 2004; Yusuf et al., } \\
\text { 2007; Omonona and Fajimi, } 2011\end{array}$ \\
\hline $\begin{array}{l}\text { Household } \\
\text { size }\left(V_{5}\right)\end{array}$ & $\begin{array}{l}\text { Number of people in the } \\
\text { household }\end{array}$ & Negative & $\begin{array}{l}\text { Loomis et al., 1994; Marchand, 1998; } \\
\text { Sansa and Kaseke, 2004; Yusuf et al., } \\
\text { 2007; Omonona and Fajimi, } 2011\end{array}$ \\
\hline $\begin{array}{l}\text { Education } \\
\qquad\left(\mathrm{V}_{6}\right)\end{array}$ & $\begin{array}{l}\text { Educational attainment of the } \\
\text { household head (years of } \\
\text { schooling) }\end{array}$ & Positive & $\begin{array}{l}\text { Loomis et al., 1994; Marchand, } \\
\text { 1998;Okojie, 2007; Yusuf et al., 2007; } \\
\text { Omonona and Fajimi, } 2011\end{array}$ \\
\hline $\begin{array}{l}\text { Residency } \\
\text { status }\left(\mathrm{V}_{7}\right)\end{array}$ & $\begin{array}{l}\text { Residency status ( } 1=\text { native, } 0= \\
\text { Non-native) }\end{array}$ & Positive & Okojie, 2007 \\
\hline $\begin{array}{l}\text { Income } \\
\left(\mathrm{V}_{8}\right)\end{array}$ & $\begin{array}{l}\text { Total household income / month } \\
\text { (\#) }\end{array}$ & Positive & Okojie, 2007 \\
\hline
\end{tabular}

Table 2. Description of Environmental Attitudinal Variables in the Logit Model

\begin{tabular}{|c|c|c|c|}
\hline Variable & Description of variable & $\begin{array}{l}\text { Hypothesized } \\
\text { relationship with } \\
\text { WTP }\end{array}$ & Source \\
\hline Forest perception $\left(\mathrm{V}_{9}\right)$ & $\begin{array}{l}\text { Belief that people can survive } \\
\text { without forests } \\
(1=\text { Yes, } 0=\text { No })\end{array}$ & Negative & Theory \\
\hline Forest dependence $\left(\mathrm{V}_{10}\right)$ & $\begin{array}{l}\text { Visit forest to benefit from its } \\
\text { numerous ( } 1=\text { yes, } 0=\text { no) }\end{array}$ & Positive & Okojie, 2007 \\
\hline Deforestation $\left(V_{11}\right)$ & $\begin{array}{l}\text { Importance attributed to } \\
\text { deforestation ( } 1=\text { Deforestation is the } \\
\text { most important issue, } 0=\text { otherwise) }\end{array}$ & Positive & $\begin{array}{l}\text { Baranzini et al., } \\
2010\end{array}$ \\
\hline Environment $\left(\mathrm{V}_{12}\right)$ & $\begin{array}{l}\text { Importance attributed to the } \\
\text { environment ( } 1=\text { environment is the } \\
\text { most important issue, } 0=\text { otherwise) }\end{array}$ & Positive & $\begin{array}{l}\text { Baranzini et al., } \\
2010\end{array}$ \\
\hline $\begin{array}{l}\text { Intergenerational } \\
\text { equity }\left(\mathrm{V}_{13}\right)\end{array}$ & $\begin{array}{l}\text { Intergenerational equity dummy } \\
\text { ( } 1=\text { support forest management for } \\
\text { future generations, } 0=\text { otherwise) }\end{array}$ & Positive & Okojie, 2007 \\
\hline
\end{tabular}

\section{Empirical results and discussion}

\subsection{Socio-economic characteristics of respondents}

Table 3 showed that the majority (81\%) of the sampled households were male headed with average age of about 49 years. 
Table 3. Distribution of household heads by socio-economic characteristics ( $N=140$ )

\begin{tabular}{|c|c|c|c|c|}
\hline Characteristics & Frequency & Percent & Mean & Std. deviation \\
\hline \multicolumn{5}{|l|}{ Age (years) } \\
\hline$\leq 30$ & 9 & 6.4 & & \\
\hline $31-40$ & 24 & 17.1 & 49.3 & 10.794 \\
\hline $41-50$ & 42 & 30.0 & & \\
\hline$>50$ & 65 & 46.4 & & \\
\hline \multicolumn{5}{|l|}{ Sex } \\
\hline Female & 27 & 19.3 & NA & NA \\
\hline Male & 113 & 80.7 & & \\
\hline \multicolumn{5}{|c|}{ Educational level } \\
\hline No formal education & 25 & 17.9 & & \\
\hline Primary education & 77 & 55 & 6.1years & 4.06 \\
\hline Secondary education & 35 & 25 & & \\
\hline Tertiary education & 3 & 2.1 & & \\
\hline \multicolumn{5}{|c|}{ Marital status } \\
\hline Married & 116 & 82.9 & & \\
\hline Single & 6 & 4.3 & NA & NA \\
\hline Widowed & 13 & 9.3 & & \\
\hline Divorced & 5 & 3.6 & & \\
\hline \multicolumn{5}{|c|}{ Household size } \\
\hline$\leq 4$ & 25 & 17.9 & & \\
\hline $5-8$ & 81 & 57.9 & 6.71 & 2.39 \\
\hline $9-12$ & 33 & 23.6 & & \\
\hline$>12$ & 1 & 0.7 & & \\
\hline \multicolumn{5}{|c|}{ Major occupation } \\
\hline Farming & 86 & 61.4 & & \\
\hline Paid employment & 4 & 2.9 & NA & NA \\
\hline Forest based activities & 38 & 27.1 & & \\
\hline Self employment & 12 & 8.6 & & \\
\hline
\end{tabular}

\section{NA = Not Applicable}

Source: Field Survey, 2011

Primary education was the common highest education attained by more than half $(55 \%)$ of the respondents. Majority (82.9\%) of the household heads are married with a mean household size of approximately 7persons. The occupational distribution shows that majority $(72.9 \%)$ of the household heads engage in non-forest activities; $61.4 \%$ of which are farmers, $8.6 \%$ are self employed and only $2.9 \%$ are wage earners. About a fourth (27\%) of the household heads' engaged in full time forest-based income generating activities.

Table 4 shows the distribution of households by household income from forest and non-forest activities, residency status and length of residency of household heads in the community, distance to nearest market and distance of nearest forest from home. 
Table 4. Distribution of Households by Other Socio-Economic Characteristics ( $N=140$ )

\begin{tabular}{|c|c|c|c|c|}
\hline Characteristics & Frequency & Percent & Mean & Std. deviation \\
\hline \multicolumn{5}{|c|}{ Forest income ( $\mathbb{A} /$ month) } \\
\hline$<5000$ & 25 & 17.9 & & \\
\hline $5001-10000$ & 34 & 24.3 & & \\
\hline $10001-15,000$ & 43 & 30.7 & $11,847.80$ & $6,906.16$ \\
\hline $15,001-20,000$ & 18 & 12.9 & & \\
\hline$>20,000$ & 20 & 14.3 & & \\
\hline \multicolumn{5}{|c|}{ Non-forest income ( $\sharp /$ month) } \\
\hline$<5000$ & 16 & 11.4 & & \\
\hline $5001-10000$ & 17 & 12.1 & & \\
\hline $10001-15,000$ & 18 & 12.9 & $19,180.38$ & $10,442.20$ \\
\hline $15,001-20,000$ & 23 & 16.4 & & \\
\hline$>20,000$ & 66 & 47.1 & & \\
\hline \multicolumn{5}{|c|}{ Residency Status } \\
\hline Non Native & 56 & 40 & NA & NA \\
\hline Native & 84 & 60 & & \\
\hline \multicolumn{5}{|c|}{ Length of residency in the community (years) } \\
\hline$\leq 10$ & 61 & 43.6 & & \\
\hline $11-20$ & 29 & 20.7 & & \\
\hline 21-30 & 15 & 10.7 & & \\
\hline $31-40$ & 14 & 10.0 & 20.77 & 17 \\
\hline $41-50$ & 12 & 8.6 & & \\
\hline$>50$ & 9 & 6.4 & & \\
\hline \multicolumn{5}{|c|}{ Distance to nearest market $(\mathrm{km})$} \\
\hline$\leq 4$ & 54 & 38.6 & & \\
\hline $5-8$ & 73 & 52.1 & 5.67 & 2.46 \\
\hline $9-12$ & 12 & 8.6 & & \\
\hline$>12$ & 1 & 0.7 & & \\
\hline \multicolumn{5}{|c|}{ Distance of nearest forest from home $(\mathrm{km})$} \\
\hline$\leq 2$ & 102 & 72.9 & 1.85 & 0.87 \\
\hline $3-4$ & 38 & 27.1 & & \\
\hline
\end{tabular}

\section{NA implies Not Applicable}

Source: Field Survey, 2011

The distribution of households by the amount of monthly income received from forest activities shows that majority (85.8\%) of the households earn less than $\$ 20,000 /$ month compare to non-forest income where only about half (52.9\%) of the households earn less $20,000 /$ month. Only $14.3 \%$ of the households receive above $20,000 /$ month from forest activities while about half (47.1\%) receive above $\# 20,000 /$ month form non-forest activities. On average, households earn income of $\$ 11,847.80$ and \#19,180.38 per month from forest-based income generating activities and non-forest activities respectively. The distribution of household heads by residency status and length of residency in the community shows that more than half $(60 \%)$ of the household heads are natives of the village and $40 \%$ are non-native. In addition, almost half (43.6\%) of the household heads have been resident in the community for about10 years while, on average, the sampled head of household have been resident in 
the community for approximately 21 years. The distance to the nearest market from home for most (52.1\%) of the households was $5-8 \mathrm{~km}$. The mean distance of the nearest market is approximately $6 \mathrm{~km}$ which is quite far and might increase households' dependence on forest resources. On the other hand, majority (73\%) of the household heads reported distance of nearest forest from their home to be about $2 \mathrm{~km}$ while the average forest distance of $1.85 \mathrm{~km}$ shows that the households' are close to forest resources. This implies that there is a high probability of them engaging in forest-based income generating activities.

\subsection{Willingness to pay responses by bid amount}

The responses to the valuation question 'yes' or 'no' to a policy which aims at implementation of the management plan by the various bid amount offered is shown in table 5 . More than half $(57 \%)$ of the total respondents said they were willing to pay for the implementation of the management plan while about $43 \%$ were not willing to pay (protest bids). A higher percentage of no responses were gotten from the respondents as the amount of bid offered gets higher.

Table 5. Willingness to pay responses by bid amount

\begin{tabular}{cccccc}
\hline Bid(A/month) & No & \%No & Yes & \%Yes & Total \\
\hline 200 & 1 & 1.67 & 3 & 3.75 & 4 \\
\hline 280 & 7 & 11.67 & 15 & 18.75 & 16 \\
\hline 360 & 7 & 11.67 & 9 & 11.25 & 17 \\
\hline 440 & 4 & 6.67 & 13 & 16.25 & 16 \\
\hline 520 & 4 & 6.67 & 12 & 15.00 & 16 \\
\hline 600 & 7 & 11.67 & 9 & 6.25 & 12 \\
\hline 680 & 1 & 1.67 & 5 & 7.50 & 12 \\
\hline 760 & 6 & 10.00 & 6 & 6.25 & 8 \\
\hline 840 & 7 & 11.67 & 5 & 2.50 & 11 \\
\hline 920 & 6 & 10.00 & 2 & 1.25 & 140 \\
\hline 1000 & 10 & 16.67 & 1 & $\mathbf{5 7 . 1 4}$ & 12 \\
\hline Total & 60 & $\mathbf{4 2 . 8 6}$ & $\mathbf{8 0}$ & & \\
\hline Source: Field Survey, 2011 & & & & & 16 \\
\hline
\end{tabular}

\subsection{Reasons for Paying}

It can be deduced from Table 6 that the respondents' main reason for accepting a bid offered for the management of community forests is because of intergenerational equity (41.25\%).

Table 6. Reasons for paying

\begin{tabular}{lcc}
\hline Reasons for paying & Frequency & Percentage \\
\hline Forests improvement & $\mathbf{2 8}$ & 35.00 \\
\hline More satisfaction & 11 & 13.75 \\
\hline Intergenerational equity & 33 & 41.25 \\
\hline The amount is quite acceptable & 8 & 10.00 \\
\hline \multicolumn{1}{c}{ Total } & $\mathbf{8 0}$ & $\mathbf{1 0 0}$ \\
\hline Source: Field Survey, $\mathbf{2 0 1 1}$ & &
\end{tabular}

This shows that the respondents are concerned about the welfare of their future generations and thus willing to pay. The second motive is that they believe the plan will lead to improvement of the community forests (35\%). The third motive is that the implementation of the management plan would improve their welfare or give them more satisfaction (13.75\%). Only $10 \%$ gave their reason for paying as an acceptable amount that is offered (10\%).

\subsection{Reasons for not paying (protest bids)}


The main reason given in Table 7 by the respondents who rejected the bid (protest bids) was that the proposed fee was too high for them (56.67\%). The second reason was that, they were so poor to pay the offered bid (25\%). Besides, $18.33 \%$ of respondents said that they would want to enjoy the public good free of charge (this is a free-rider behavior).

Table 7. Reasons for refusing to pay (protest bids)

\begin{tabular}{lcc}
\hline Reasons for paying & Frequency & Percentage \\
\hline High bid & 25 & 56.67 \\
\hline I am poor & 20 & 25.00 \\
\hline $\begin{array}{l}\text { The project should be free of } \\
\text { charge }\end{array}$ & 15 & 18.33 \\
\hline Total & $\mathbf{6 0}$ & $\mathbf{1 0 0}$ \\
\hline Source: Field Survey, $\mathbf{2 0 1 1}$ & & \\
\hline
\end{tabular}

\subsection{Mean Willingness to Pay for Community Forests Management by Rural Households}

The result of the logit regression is shown in Table 8. The mean WTP estimated with the restricted mean formula using the relevant parameter estimates from the logit result as specified in the methodology is \#389.04/month. The result shows that the mean WTP is positive. The non-zero value shows that the forest community households would vote positively for the management of the community forests. The non-zero value is also a reflection of the perceived social and economic benefits of the resource in the livelihood of the forest communities. The households WTP for sustainable management of the forest resources will directly improve their welfare also.

Table 8. Mean Willingness to Pay

\begin{tabular}{ccc}
\hline Variable & Coefficient & t-ratio \\
\hline Constant & 3.219 & \\
& $(0.613)$ & $5.251^{* * *}$ \\
Bid & -0.008375 & $-4.571^{* * *}$ \\
& $(0.0018)$ & \\
\hline Log likelihood function: & -76.94308 & \\
Restricted log likelihood: & -89.34125 & \\
Chi-squared: & $24.79633^{* * *}$ & \\
\hline
\end{tabular}

*** Coefficients significant at $1 \%$. Standard errors are in parenthesis

Source: Field Survey, 2011

\subsection{Factors Influencing Willingness to Pay}

The result of the logit regression of the factors influencing the probability of rural households' willingness to pay for community forests management is presented in Table 9. The log likelihood value of the model is -53.44138 . The chi-square (LR-statistics) value of 71.79973 is statistically significant at $1 \%$ level shows the overall goodness of fit of the model and confirms that the slope coefficients are significantly different from zero. In other words, the explanatory variables are collectively significant in explaining the determinants of being willing to pay for community forest management $(p<0.01)$. Bid, age, education, income, forest perception, deforestation importance and intergenerational equity are important factors that influence WTP for community forests management. The bid in conformity with the microeconomic theory has a negative and significant effect $(p<0.01)$ on the households probability of bid acceptance for community forest management. This is similar to the findings of Tameko et al. (2011). It is also a confirmation of the assertion of Okojie, (2007) of expected negative relationship between price and quantity of environmental good (forest management). This corroborates the findings of Okojie (2007), Yusuf et al., (2007) and Omonona and Fajimi (2011). The marginal effect on probability of households paying for the service with respect to bid is -0.00182 . This implies that for every 1 increase in the bid offered to the respondents, the likelihood of the households paying the price reduces by 0.00182 units. The age of household head was found to have a positive and significant effect $(p<0.10)$ on the probability of bid acceptance for community forests management in the study area. The result 
reveals that the marginal effect on probability of household heads paying for the management of community forests with respect to age is 0.01022 . This means that as age of household head increases by one year, the likelihood of paying for community forests management increases by 0.01022 units. This implies that older headed households worry about the wellbeing of the future generations and are thus willing to pay more for community forests management.

Table 9. Result of Binary Logit regression

\begin{tabular}{|c|c|c|c|}
\hline \multirow[t]{2}{*}{ Variable } & \multicolumn{3}{|c|}{ Marginal effect on probability of willingness to pay } \\
\hline & Coefficients & Standard error & Z-statistics \\
\hline Constant & -0.7193 & 2.0931 & -1.847 \\
\hline Bid & -0.00182 & 0.0025 & -3.899 \\
\hline Age & 0.01022 & 0.0284 & 1.937 \\
\hline Gender & 0.05410 & 0.7429 & 0.392 \\
\hline Marital status & 0.1183 & 0.6558 & 0.97 \\
\hline Household size & 0.0140 & 0.1247 & 0.605 \\
\hline Education & 0.0370 & 0.0809 & 2.457 \\
\hline Residency status & 0.0918 & 0.5265 & 0.937 \\
\hline Income & $0.75 E-05$ & $0.2514 \mathrm{E}-04$ & 1.688 \\
\hline Forest perception & -0.2470 & 0.5564 & -2.389 \\
\hline Forest dependence & 0.0659 & 1.0922 & 0.324 \\
\hline Deforestation importance & 0.2740 & 0.5180 & 2.843 \\
\hline Environment importance & -0.1010 & 0.5145 & -1.053 \\
\hline Intergenerational equity & 0.1960 & 0.5354 & 1.966 \\
\hline Log likelihood & -53.44138 & & \\
\hline Restricted log likelihood & -89.34125 & & \\
\hline Chi-square & $71.79973 * * *$ & & \\
\hline \multicolumn{4}{|c|}{ ***significant at 1 percent } \\
\hline \multicolumn{4}{|c|}{ **significant at 5percent } \\
\hline *significant at 1 & & & \\
\hline
\end{tabular}

Source: Field survey, 2011

The educational level of the household heads (measured by the number of years spent in school) has a positive and significant effect $(p<0.01)$ on the probability of the households paying a given price for community forests management. This implies that household heads that are better educated have a higher probability of paying for the management of community forests. This corroborates the findings of Okojie (2007), Yusuf et al., (2007) and Omonona and Fajimi (2011). The result reveals that the marginal effect on probability of household heads paying for the service with respect to educational level is 0.037. This implies a unit increase in the number of years spent in school by the household head will increase the likelihood of households paying for community forests management by 0.037 units. This confirms the assertion of Okojie (2007) that a positive correlation exits between education and increase likelihood to pay for rainforest protection. The total household income as the expected has a positive and significant effect $(p<0.10)$ on probability of acceptance of the bid elicited for community forests management which corroborates the findings of Okojie (2007). The result reveals that the marginal effect on probability of household heads paying for the service with respect to the total household income per annum is 0.00000065 . This implies that for every $\# 1$ increase in total household income per annum, the likelihood of paying for the management of community forest in the study area increases by 0.0000075 units. 
The relative importance attributed to deforestation compared to issues such as climate change, water and air pollution, soil erosion and loss of fertility and global warming positively and significantly $(p<0.05)$ influenced the likelihood of bid acceptance for community forests management. This result is similar to the findings of Baranzini et al. (2010). The result reveals that the marginal effect on probability of household heads paying for the service with respect to the importance attributed to deforestation is 0.274 . This implies that when the household heads perceive deforestation to be the most important, the likelihood of paying for the management of community forest increases by 0.274 units. However, forest perception (measured by the belief that people can survive without forests) as expected negatively and significantly $(p<0.05)$ influenced the household heads probability of paying a given price for the management of community forests. The result reveals that the marginal effect on probability of household heads paying for forests management with respect to forest perception is -0.247 . This implies that when the respondents believe that their survival is not dependent on forests, the likelihood of paying for the management of community forest in the study area decreases by 0.247 units. In addition, as expected, the coefficient on intergenerational equity is positive and significant $(p<0.05)$ which shows that the household heads are very considerate to the wellbeing of future generations. The higher the household heads support forest management for the future generations the higher the probability of paying the bid elicited for the management of community forests. This is similar to the findings of Okojie (2007). The result shows that the marginal effect on probability of household heads paying for forests management with respect to intergenerational equity is 0.196 . This implies that when the household heads supports the management of forests for the future generations, the likelihood of paying a given price for the management of community forest in the study area will increase by 0.196 units.

\section{Conclusion}

The rural households were willing to pay for community forests management in the study area. This showed that the rural households demand for Community forests management in which the improved community forests will directly improve their welfare. Age, education, income, importance attributed to deforestation and intergenerational equity are important factors that influence the likelihood of being willing to pay for the management of community forests in the study area. Based on the findings, the study recommends that:

increase access to education among rural male headed households so as to raise the educational and social status of the rural dwellers which will help reduce dependence on forest resources and enhance community forest management;

increase rural development policies that will improve the non-forest dependent sectors and as well provide other alternative sources of income to help improve the income level and mitigate pressure on the community forests and provide broader social and ecological benefits to the society; and

increase government efforts to include the rural communities in the management of community forests as the rural people are willing to pay for its management which will help ensure sustainable management of forest resources and as well improve the welfare of the rural households.

\section{References}

Agbonlahor M.U. (2010), Productivity Dispersion and Sources of Technical Inefficiency in Small Holder Timber Mills in Ogun State, Nigeria, Journal of Humanities, Social Sciences and Creative Arts, 5(1), 23-42.

Arnold M. and Townson I. (1998), Assessing the potential of forest product activities to contribute to rural incomes in Africa, ODI, Natural Resource Perspectives, 37(November).

Baranzini A., Faust A. and Huberman D. (2010), Tropical forest conservation: Attitudes and Preferences, Forest Policy and Economics, 12, 370-376.

Beak Consultants (1998), Forest Resources Study, National Report (draft), Vol. 1. 
Bergland O., Musser W., Musser I. and Terry K. (1987), Optimal sampling intensities in close-ended contingent valuation methods. Draft Paper. Department of Agricultural Economics, Oregon State University, Corvallis, Oregon.

Bryon N. and Arnold J.E.M. (1997), What Futures for the People of the Tropical Forests? CIFOR Working Paper No 19. Centre for International Forestry Research (CIFOR), Indonesia.

Carson R.T., Hanemann W.M., Kopp R.J., Krosnik J.A., Mitchell R.C., Presser S., Ruud P.A., Smith V.K., Conaway M. and Martin K. (1995), Referendum design and contingent valuation: The NOAA panel's no vote recommendation. Discussion paper 96-05, Washington, D.C.: Resources for the Future.

Chukwuone N.A. and Okorji C.E. (2008), Rob B. Dellink and Arjan Ruijs (eds.), Economics of Poverty, Environment and Natural- Resource Use, 117-137.

CIFOR, 2005.Contributing to Africa's Development through Forests Strategy for Engagement in sub-Saharan Africa. Centre for International Forestry Research, Bogor, Indonesia. 35pp.

Cooper J. (1993), Optimal bid selection for dichotomous choice contingent valuation surveys, Journal of Environmental Economics and Management, 24, 25-40.

Food and Agricultural Organization, (2005). State of the world's forests 2005. FAO, Rome. [http://www.fao.org/docrep/007/y5574e/y5574e00.htm]

Hanemann M. (1989), Welfare Evaluations in Contingent Valuation Experiments with discrete Responses Data, American Journal of Agricultural Economics, 71(4), 1057-1061.

Hanemann M.W. (1984), Welfare evaluations in contingent valuation experiments with discrete response. American Journal of Agricultural Economics, 66, 332-341.

Inoni O.E. (2009), Effects of Forest Resources Exploitation on the Economic Well-Being of Rural Households in Delta State, Nigeria, Agricultura Tropica et Subtropica, 42(1), 20-29.

Johansson P.O. (1993), Cost-Benefit Analysis of Environmental Change. Cambridge University Press.

Kaimowitz D. (2003), Not by bread alone. Forests and rural livelihoods in Sub-Saharan Africa. In: Oksanen, T., Pajari, B., Toumasjukka, T. (Eds.), Forests in Poverty Reduction Strategies: Capturing the Potential, European Forest Institute, Joensuu, Finland, 45-63pp.

Loomis J., Gonzalez-Caban A. and Gregory R. (1994), Do Reminders of Substitute and Budget Constraints Influence Contingent Valuation Estimates, Land Economics 70(4), 499-506.

Marchand R. (1998), Marketing of solid waste management services in Tingloy, the Philippines: a study on affordability and willingness to pay, UWEP Working Document No 9, Gouda, the Netherlands.

Mathur A.S. and Sachdeva A.S. (2003), Towards an Economic Approach to Sustainable Forest Development. Working Paper Series Paper No. 2.

Mitchell R.C. and Carson R.T. (1989), Using Surveys to Value Public Goods: The Contingent Valuation Method. Washington, D.C., Johns Hopkins University Press.

National Oceanic and Atmospheric Administration, (1993). Natural resources damage assessments under the Oil Pollution Act of 1990, Federal Register 58(10), 4601-4614.

Okojie L.O (2007), Willingness to Pay for Rainforest Protection and Implications on Food Crop Production in Ogun State, Nigeria. A Ph.D Thesis submitted to the Department of Agricultural Economics, Faculty of Agriculture and Forestry, University of Ibadan, Ibadan.

Omonona B.T and Fajimi F.O. (2011), Households Willingness to Pay for Improved Water Supply Services in Ibadan Metropolis of Oyo State, Nigeria, New York Science Journal, 4(4), 72-76.

Sansa A. and Kaseke N. (2004): Welfare Gains Due to Improved Solid Waste Management: A case study of Bugoloobi flats, Kampala. pp 1-20

Tameko A.M., Donfouet H.P. and Sikod F. (2011), The Economic Valuation of Improved Urban Parks: A Case Study of Warda Park, Journal of Sustainable Development, 4(1), 271-280.

United Nations. (2002). Nigeria country profile: political and socio-economic situation. United Nations Office on Drugs and Crime (UNODC). [http://www.unodc.org/nigeria/en/social_context.html]

Yusuf S.A., Ojo O.T. and Salimonu K.K. (2007), Households' Willingness to Pay for Improved Solid Waste Management in Ibadan North Local Government Area of Oyo State, Nigeria, Journal of Environmental Extension, 6, 57-63. 